\title{
Right to Education (RTE): A Critical Appraisal
}

\author{
Uma \\ (Research Scholar, Department of Public Administration, Panjab University, Chandigarh, India)
}

\begin{abstract}
The importance of education cannot be denied in one's life. It sustains the human values which contribute to the individual and collective well-being. It forms the basis for lifelong learning and inspires confidence to face challenges. It provides the skills to individuals to become more self reliant and aware of right opportunities. It also enhances the ability of individuals to act more responsible and more informed citizens and have a voice in politics and society, which is essential for sustaining democracy. It is essential for eradicating poverty and it allows people to be more productive and playing greater roles in economic life and earning a better living. The education is the key which allows people to move up in the world, seek better jobs, and ultimately succeed in their lives. So education is very important, and none should be deprived of it. The importance of primary education has been neglected by India since independence knowingly or unknowingly. However, Government of India now is willing to improve primary education by bringing legislation i.e. Right to Education. The paper tries to bring out the meaning of much awaited Right to Education (RTE) 2009, act and tries to bring out the critical appraisal of the Act after three years since its passage.
\end{abstract}

Keywords: Education, Right to Education Act, promises of the act, consistent political will and attention

\section{Introduction and Literature Review:}

Education is now widely valued not only for its intrinsic value in enriching the lives of individuals but also for its functional value in the development of the human capital of a nation. Educational investments in children have been shown to have high private and social returns. The private returns are associated with increased productivity and earnings in adulthood, and with further non-pecuniary gains arising from the greater efficiency with which educated individuals are able to acquire and process information (Rosenzweig 1995). The social premium to education over and above the private value includes further productivity increases arising from knowledge spillovers, gains in health for one generation that flow from gains in education for the previous, and the improved functioning of civic society and democracy. These examples illustrate that widespread education not only helps growth through productivity effects, but is also crucial to distribution of the gains from growth. Growth in a society in which most people have a basic education is most likely more pro-poor than growth in a society in which the educated are the elite few. Also, there is widespread evidence of an intergenerational correlation in educational attainment (Becker and Tomes 1986), at least some of which is thought to becausal (e.g. Lleras-Muney 2001, Chevalier 2004). To the extent that the impact of parental education on child education is causal, there are significant knock-on effects of public investment in education. In other words, they payoff to policy immediately goes up because investments in education at any one time have a multiplier effect, yielding additional benefits in the future. In summary, education is a powerful tool for reducing poverty, unemployment and inequality, improving health and nutrition and promoting sustained human development led growth (World Bank (2004), p.69). One of the Millenium Development Goals (MDGs) agreed in September 2000 at a UN summit of world leaders is the achievement of universal primary school

Attendance for boys and girls, this, of course, implies a complete closing of the gender gap. It also requires a 100\% primary school completion rate, that is, that all students entering grade 1 are retained until grade 5. The MDG couched in these terms reflects recognition of the importance of basic (primary) education. This is particularly pertinent in India where primary education has historically been neglected by the state, with educational expenditures being concentrated on the tertiary sector (e.g. Dreze and Sen 1995). As a result, there are vast inequalities in educational attainment in India, a remarkable degree of illiteracy coexisting with frontier research in science and technology. India is also marked for being one of the group of countries in South Asia and Northern Africa where outcomes tend systematically to be better for boys than for girls, suggesting gender discrimination or at least undesirable gender differentiation. A further reason that India offers an interesting case study is that it exhibits striking diversity in educational indicators across its states that, in further work, we will exploit to consider more carefully the sorts of policy interventions that are likely to be effective. With India being such a large country, sample sizes available for statistical analysis are large, allowing more general pursuit of heterogeneity in the data- for example by religion (Muslims have lower educational attainment than Hindus) or by caste (scheduled castes and tribes exhibit lower educational attainment than the higher-castes). The NFHS data show that, in India in 1998-89, the school attendance rate was $82.5 \%$ and the primary school completion rate was $61.7 \%$. We argue in this paper that it is challenging, a priori, to expect both of these rates to rise to 
$100 \%$ by 2015. The future prospect of every nation lies in the hands of children and illiteracy is one of the major hindrances for them. Universal schooling accompanied by quality, equity and accessibility can be a single big move towards attaining future prosperity of every nation. Education should be provided in such a manner that ensures children can benefit from it. Right to Education (RTE) has been passed by Indian Legislature. The challenges which have been reported after the three years of passage of bill have been discussed in this paper.

\section{Right to Education Act: Background and Meaning}

Every child between the ages of 6 to 14 years has the right to free and compulsory education. This is stated as per the $86^{\text {th }}$ Constitution Amendment Act added Article 21A. The right to education act seeks to give effect to this amendment. The government schools shall provide free education to all the children and the schools will be managed by School Management Committees (SMC). Private schools shall admit at least 25\% of the children in their schools without any fee. The National Commission for Elementary Education shall be constituted to monitor all aspects of elementary education including quality.

\section{- December 2002}

$86^{\text {th }}$ Amendment Act (2002) via Article 21A (Part III) seeks to make free and compulsory education a Fundamental Right for all children in the age group 6-14 years.

\section{- October 2003}

A first draft of the legislation envisaged in the above Article, viz., Free and Compulsory Education for Children Bill, 2003, was prepared and posted on this website in October, 2003, inviting comments and suggestions from the public at large.

\section{- 2004}

Subsequently, taking into account the suggestions received on this draft, a revised draft of the Bill entitled Free and Compulsory Education Bill, 2004.

\section{- June 2005}

The CABE (Central Advisory Board of Education) committee drafted the 'Right to Education' Bill and submitted to the Ministry of Human Resources and Development (MHRD). MHRD sent it to NAC (National Advisory Council). NAC sent the Bill to Prime Minister for his observation.

\section{- 14th July 2006}

The finance committee and planning commission rejected the bill citing the lack of funds and a model bill was sent to states for the making necessary arrangements. (Post-86th amendment, states had already cited lack of funds at State level) July 19, 2006

Campaign against Child Labor (CACL), National Alliance to Fundamental Right to Education (NAFRE), CABE invited Indian Literacy Project (ILP) and other organizations for a Planning meeting to discuss the impact of the Parliament action, initiate advocacy actions and set directions on what needs to be done at the district and village levels.

\section{Present}

The present Act has its history in the drafting of the Indian constitution at the time of Independence. However, are more specifically to the Constitutional Amendment that included the Article $21 \mathrm{~A}$ in the Indian constitution making Education a Fundamental Right. This amendment, however, specified the need for a legislation to describe the mode of implementation of the same which necessitated the drafting of a separate Education Bill. The rough draft of the bill was composed in year 2005. It received much opposition due to its mandatory provision to provide $25 \%$ reservation for disadvantaged children in private schools. The subcommittee of the CABE which prepared the draft Bill held this provision as a significant prerequisite for creating a democratic and egalitarian society. Indian Law commission had initially proposed 50\% reservation for disadvantaged students in private schools. The government drafting this piece of legislation, however lost the elections, and the new government came up with its own version. This passed the approval of the cabinet on November 1, 2008, was tabled in Parliament in 2008 and passed in 2009.

\section{Passage}

The bill was approved by the cabinet on July 2, 2009. Rajya Sabha passed the bill on July 20, 2009 and the Lok Sabha on August 4, 2009. It received Presidential assent and was notified as law on September 3, 2009 as the Children's Right to Free and Compulsory Education Act. 


\section{Some of the Highlights of the Historic Right to Education Act}

*Every child in the age group of 6 to 14 years will have a right to free and compulsory education in a nearby school.

* Private and unaided educational institutes will have to keep $25 \%$ of the seats for students belonging to the weaker sections.

* No child would be failed or expelled and will not be required to pass any board examination till the age of 14 .

*All students who complete their elementary education will be awarded certificates.

* Financial burdens will be shared between the center and states.

*Infrastructure of schools will be improved; Recognition will be subject to improvement.

*Quality of education will be improved.

\section{Research Questions}

1. Does RTE justify the age group of 6-14?

2. Does RTE provide what it promises?

3. Does RTE compromise the quality issue?

4. Do the parents prefer the Government Schools after passage of the act?

\section{Scope of the Study}

The main cities of India namely Chandigarh, Delhi, Mohali, Jaipur, Dehradun, Hyderabad, Banglore and Kolkatta cities have been selected as the locale of the study. Right to Education act has been passed in 2009. Hence, the time period of study is 2009-12. This will allow bringing out the provisions, challenges, and the answers to research questions involved within.

\section{Research Methodology}

The study is based on Primary and Secondary data. Various techniques of data collection such as observations, interviews and online questionnaires were administered. The random sample of 200 people mainly educational administrative authorities, principals, teachers of primary schools was interviewed. Online questionnaires were administered on the service class people. The sampling used is random and convenient sampling. Published reports, news reports of news channels, articles in journals and newspapers, websites, blogs were used.

\section{Findings}

1. Age Group in RTE: RTE talks about the age group which starts from the age 6. However, in India the elementary education starts with the age of 2 and half years of age. The schools take the kids in pre-nursery if they are three years of age. A child who has an early schooling since the age of 3 will be far ahead from the child who enters the school at the age of 6 . Therefore, the act does not take care of the age below six. The age taken can not be justified and right. The act should be reviewed again and the age should be revised in this regard.

2. Promises of RTE: RTE promises a lot as said before, however the challenges to achieve the objectives and promises are many. Some of the main challenges brought forward are as follows:

- Financial Challenges: Government of India is already beset with various financial hurdles and challenges because of the implementation of RTE. According to Act the fiscal burden has to be shared between the center and the states in the ratio of 55:45 and 90:10 for the North-Eastern States. This project involves funds to the tune of Rs. 15,000 crore. Many states of India like Bihar, Uttar Pradesh and Punjab have already expressed their incapability to mobilize funds that they would not be able to implement the Act in the absence of funds from the center and a situation of dispute has raised between the center and the states. The state of Orissa wants the same status as by the North Eastern states with respect to the Act. The achievement as far as the financial matters are concerned largely depends upon the co-operation between the states and the center. It has been reported that the striving project is already falling short of around Rs.7, 000 crore in the very commencing year. In view of the fact the Act involves improving the infrastructure of schools, training of teachers, creating more facilities in the schools besides the manifold increase in intake, big investments would be involved and it is an uphill task to predict how the economics of it all will be worked out.

- Challenge of Hiring Qualified Teachers: The scarcity of good and qualified teachers for government schools is going to be one of the hardest tasks to be achieved in implementing the act. The teachers are considered to be the backbone of education, in their absence the act can not achieve the goals. It is a fact that, about one fourth of the teachers of government school remains on leave in India at any given point of time and most of them are not able to do full justice to their professions due to numerous reasons. The act makes it evident that school drop outs and others kids who are unable to get education, would be brought back into 
the education stream again, it demands hiring almost double the number of teachers. The teachers of primary schools agreed that there are hundreds of students in one class and there is a huge gap between the training imparted to teachers and what they practice on ground. India's Human Resource Development Minister himself has accepted that there is a shortage of about five lakh teachers.

- Challenge to Provide Infrastructure: The survey done in the Government Primary Schools of Mohali city schools revealed that there are no basic facilities provided to children. The students sit on the floors and there are no separate toilets for students in the school. The principal does not have a separate office. No separate kitchen to prepare mid-day meals could be seen in all of the primary schools. Another survey on 'Elementary Education in India', conducted by the National University of Educational Planning and Administration (NUEPA), add to the fact that almost half of the recognized elementary schools in the country do not have separate toilets for girls. This brings out the sorry picture of India's schools are in. To achieve requisite infrastructure that the Act expects is a great challenge to provide. The Act also demands that the buildings of all the schools should be weather proof. Basic facilities of drinking water, playground for kids, and barrier free entries are also lacking in most of the government schools. Also the teacher pupil ratio should be 1:30, which is not there. It has been reported that only about $40 \%$ of the schools have ramps. The current scenario seems that to provide the necessary infrastructure to the schools is a great challenge. There is no clear demarcation between the responsibilities of the center and state and it seems to be a challenge to work out the details.

- Quality in Education: Human Resource Minister has paved the way for huge challenges ahead by promising quality education to all. As it has already been brought out that it will be difficult to do so in the absence of good teachers. The Act says that no student would be dropped from school or not passed till the age of 14. The starkest finding of three consecutive annual statuses of education reports published by Prahtam, a community-based organization, reveals more than half of class $\mathrm{V}$ students across India's government primary schools, can't read basic class II text book. This raises the quality issues being compromised through the act.

- Enforcement of 25\% Quota for Weaker Sections: The act gives a clause of reservation of 25\% of seats for weaker sections by private unaided schools turns out to be a boon or a bane. By this clause the government itself accepts that the government schools are not capable of giving good quality education. Meanwhile, confront is to define weaker sections. The malpractices can creep in through this mechanism. A well monitored mechanism needs to be set up to ensure its fair implementation of the clause. Also, it is tough task to bring together children from varying economic and social backgrounds on the same platform. The interviews with the parents of slum near Chandigarh (Janta Colony) revealed that they would like to avail this Right and put their child in a good private primary school it was found that they preferred private school, as they feel that they provide better education and infrastructure, However, the working maids in Delhi prefer government schools, the reasons which had been observed were that being illiterate, making the certificates to prove the weaker section, was a hassle for them and moreover they were not comfortable in putting their child in such a vast economically different environment plus they feel that the teachers and the principals themselves actually do not want to give admissions to their wards and if forced to give admissions to their children they are not given due respect and love by the teachers and class mates, so to avoid any mental pressure or agony, the poor still prefer government schools. It would indeed be challenging for the teachers to maintain equilibrium and create an environment for them to blend together.

- Challenge to Bring Child Laborers to Schools: RTE has become a fundamental right of each and every child, therefore, the children who are out of schools and are child labours should be brought back to schools. There are more than 12 million children in India who are engaged in child labor according to official figures. The act brings India in the same league as USA and 130 nations which have the concern for right to education. Therefore to be up to mark with this nations India has to work hard for this child labor issue and providing education.

- Preference of Parents: The parents prefer private schools for the primary schooling for their kids. The interviews with most primary school teachers, authorities' in Mohali and Chandigarh region revealed that they had preferred or will prefer private schools for their kids. 95\% people surveyed online and interviewed had preferred private primary schools for their kids. The reasons cited were that the private schools provide better infrastructure, qualified staff and quality education. The environment of private primary schools inculcates a great confidence in the personality of the kid. However, all these people agreed that private schools charge the fees on their discretion. And one more interesting fact that came out that none of the surveyed or interviewed person agreed that the child who gets education in government primary schools lags behind in the career opportunities. Still the preferred choice of parents came out to be Private Primary schools.

Suggestions: The above discussion brings that that it is a great responsibility for government to shoulder if the promises of the acts to be kept. Some suggestions in this regard have been put forward. 
Provision of Infrastructure in Schools: The government should give the time based projects. First the government should invest in the building and infrastructure and then open a school. But here it is different. The school appears in papers and files first the building appears years' later. The other solution is that the government has many good government senior secondary schools like central schools, Jawahar Navodaya Vidyalayas and other government senior secondary schools with better infrastructures. These buildings can be used for primary schools. The shifts can be made for the school timings. The $11^{\text {th }}$ and $12^{\text {th }}$ class can have evening shifts. This can save a lot of investments to be made in the infrastructure of government primary schools.

The Regional Balance in Opening New Schools should be Maintained: The government schools should be opened where they are needed very much. An imbalance can be seen in the rural and urban sector of the school. For example in Mohali, Chandigarh and Dehradun city, one can find many government and private recognized school within the range of $1 \mathrm{Km}$, whereas you can not find a good school in the remote rural areas of India. The government primary schools in these areas are in very pitiable conditions. The government can take care of this regional imbalance while opening or giving recognition to these schools. The government can instruct private sector to come forward to open the schools in the remote rural areas where the schools are far. It will solve the purpose of imparting quality education in the far furlong areas as well. The schools should be only there where they are needed i.e. remote rural areas to vanish the regional imbalance in imparting the education.

The Teachers of Primary School Should be Free from Extra duties: According to the teachers of primary schools in Mohali city the teachers are involved in many other duties other than teaching for example, the maintenance of building, to supervise the construction work and supply of the material, to check the preparation of mid day meal and to send the correspondences. All these disturb the main function of the teachers. Their main duty is to provide education to the children. Therefore, it is suggested that the teachers should be involved into their basic duties of imparting education.

Active Youth, NGOs and Civil Society's Participation: The awareness through civil society, youth, and NGOs has to be made for the weaker section to avail the rights and to accept them as a part of our society. All of us have to accept them with open heart to study with our kids' disregard of the fact of their socio economic background.

\section{Conclusion}

Therefore, in the concluding remarks it is wished to state that passing an act is not sufficient. The need of hour is to implement and monitor the act properly. The consistent monitoring and intention of the political will is a must to make it successful. According to the UNESCO's 'Education for All Global Monitoring Report 2010', about 135 countries have constitutional provisions for free and non-discriminatory education for all. The much awaited Right to Education (RTE) Act which has been passed by the parliament of India should play an important role in achieving universal elementary education in India. The success and failure of RTE would largely depend on consistent political attention. Budgetary allocation of funds should be sufficient in this respect. The youth and civil society in India should come forward and spread the usefulness of education to illiterate parents who are unable to appreciate the relevance of education in curbing the social evils. Social inequalities and monopolization by any group should not be permitted at any cost. Education which is free of cost up to a certain age must be accessible to all. . The right to education is a fundamental right and UNESCO aims at education for all by 2015. India along with other countries of the world should also put sincere efforts to make this goal a real success.

\section{References}

[1] Becker, G. and N. Tomes "Human capital and the rise and fall of families", Journal of Labor Economics, 1986,4, S1-S39.

[2] Chevalier, A. Parental Education and Child's Education: A Natural Experiment, IZA Discussion Paper No. 1153, May 2004,

[3] Dreze, J. and Amartya, S. India-Economic Development and Social Opportunity, New Delhi: Oxford University Press 1995.

[4] Government of India, RTE Act 2009.

[5] Government of India, Ministry of Human Resource Department, Department of School Education and Literacy, Department of Higher Education, Annual Report, 2006-07.

[6] Government of India, Education in Eleventh Five Year Plan, 2007-12

[7] http://www.dnaindia.com/india/report right-to-education-act-implemented-challenges-still-remain 1366189 as on January 5 , 2012.

[8] http://ibnlive.in.com/news/many-challenges-before-right-to-education/112494-37.html as on January $5,2012$.

[9] Lleras-Muney, A.2001, The Relationship between Education and Adult Mortality in the US. Mimeograph, Princeton University.

[10] Mohini Jain Vs. State of Karnataka AIR1992 SC 1858

[11] Jha, Praveen and Pooja Parvathi 2010, Right to Education Act: 2009, Critical Gaps and Challenges, Economic and Political Weekly, March Vol XLV (13).

[12] Rosenzweig, M.1995, "Why are there returns to schooling”, American Economic Review, 85(2), May, $153-158$. 
[13] UnniKrishnan, J.P. VS. State of Andhra Pradesh

[14] T.M.A Pai Foundation Vs. State of Karnataka, AIR2003 SC 355

[15] National Sample Survey, March21, 2007

[16] A Human Rights based approach to education for all. UNESCO and UNICEF (2007)

[17] Minority Schools of Albania, Advisory opinion, Series A/B-No.64 (1935)

[18] http://www.airwebworld.com/articles/index.php?article=1515 as on January 21,2012

[19] http://www.indiastudychannel.com/resources/111415-Right-Education-Act-India-The-Challenges.aspx as on January, 2012

[20] http://pib.nic.in/newsite/erelease.aspx?relid=35611 as on February 3, 2012

[21] World Bank 2004, Attaining the Millenium Development Goals in India: Role of Public Policy and Service Delivery: Human Development Unit, South Asia Region, June.

[22] http://www.pratham.org/ as on January, 2012 